\title{
Wartość w ekonomii społecznej
}

\begin{abstract}
Jakub Głowacki*
Streszczenie: $\quad$ W artykule dokonano przeglądu najważniejszych teorii wartości, począwszy od starożytności, aż do czasów współczesnych. Przytoczono poglądy w sprawie określania wartości dóbr i usług m.in. Arystotelesa, Adama Smitha, Ludwiga von Misesa czy Petera Burke'a. Na podstawie tych rozważań podjęto próbę sformułowania definicji społecznej wartości dodanej tworzonej przez podmioty sektora ekonomii społecznej, co będzie punktem wyjścia do opisania metod pomiaru dokonań w ekonomii społecznej.
\end{abstract}

Słowa kluczowe: wartość, cena, dobra i usługi, pieniądz, monetyzacja, społeczna wartość dodana.

\section{Wprowadzenie}

Antoine de Saint-Exupéry stwierdził: „Diament ma wartość, kiedy go wydobywasz, kiedy go sprzedajesz, kiedy go ofiarowujesz, kiedy go tracisz, kiedy go odzyskujesz, kiedy zdobi czoło w dniu święta. Nie znam wartości zwykłego diamentu. Bowiem diament dnia powszedniego jest zwyczajnym kamieniem". Cytat ten dobrze oddaje wieloznaczność pojęcia „wartość", które w sektorze ekonomii społecznej jest kategorią szczególną. To tutaj tworzenie wartości jest bardzo często niewymierne i prezentowanie własnych osiągnięć w ekonomiczno-finansowej formie jest mocno utrudnione. Dlatego w niniejszym artykule podjęto próbę usystematyzowania dorobku naukowego w zakresie teorii wartości i rozumienia pojęcia społecznej wartości dodanej, a to z kolei będzie bazą do rozważań nad sposobami pomiaru tej kategorii w kolejnych planowanych tekstach. Artykuł składa się z dwóch zasadniczych części. W pierwszej podjęto próbę uporządkowania najważniejszych teorii wartości, które zostały sformułowane od okresu starożytności do czasów współczesnych, uwzględniając między innymi dorobek Artystotelesa, A. Smitha, L. von Misesa czy P. Burke'a. Druga część tekstu syntetycznie pokazuje sposoby rozumie- nia pojęcia społecznej wartości dodanej, które to $w$ literaturze naukowej nie jest mocno rozpowszechnione.

\section{Teorie wartości i ceny - przegląd historyczny}

Pierwsze rozważania dotyczące wartości dóbr prowadzone były w starożytnej Grecji. Rozwój tej myśli spowodowany był silną ekspansją kupiectwa, które wraz z rozpowszechnieniem spekulacji oraz lichwy zagrażały interesom arystokracji ziemskiej. Ówcześni myśliciele, pozostając pod silnym wpływem poglądów tej grupy społecznej, nadrzędną rolę przypisywali rolnictwu, jako dziedzinie, która stanowiła podstawę egzystencji ludzkości. Spośród szerokiej rzeszy filozofów tamtych czasów, w pierwszej kolejności należy wspomnieć o dwóch z nich, którzy pośrednio w swoich rozważaniach zajmowali się tematem wartości dóbr.

Ksenofont był jednym z pierwszych myślicieli, którzy poruszali w swoich dziełach te-

\section{* Jakub Głowacki}

Katedra Gospodarki i Administracji Publicznej

Uniwersytet Ekonomiczny w Krakowie

ul. Rakowicka 27, 31-510 Kraków

e-mail: jakub.glowacki@uek.krakow.pl 
matykę wartości. W księdze O gospodarstwie (gr. Oikonomikos - oikos 'dom', nomos „prawo') [Ksenofont, 1967] wprowadził on pojęcie „ekonomii", czyli nauki o gospodarstwie domowym, sztuki zarządzania własnym majątkiem. Ksenofont wskazywał na podział pracy w społeczeństwie według kwalifikacji zawodowych, co przyczynia się do wzrostu wartości użytkowych wytwarzanych dóbr. Autor rozróżnia kategorię wartości wymiennej i wartości użytkowej, wskazując, że jedynie rzeczy użyteczne mają swoją wartość. Twierdził, że dla kupca lutnia ma wartość bez względu na to, czy posiada umiejętność gry na niej. Dla nabywcy ta sama lutnia jest warta tylko wówczas, gdy potrafi na niej grać [Kundera, 2004, s. 100-101].

Arystoteles, jeden z najwybitniejszych myślicieli i uczonych starożytności, rozróżniał dwie dziedziny nauki o pomnażaniu bogactwa - ekonomię i chremastykę [Romanow, 1995 , s. 8]. Pierwsza z nich zajmuje się bogactwem społeczeństwa, na które składają się wyłącznie wartości użytkowe. Ekonomia w takim ujęciu zakłada zatem, że człowiek gromadzi środki wyłącznie w celu zaspokojenia własnych potrzeb, a wówczas proces bogacenia nie jest celem samym w sobie. Chremastyka natomiast bada bogactwo $w$ formie pieniężnej i zalicza się do niej handel i lichwę, które to, zdaniem Arystotelesa, są niemoralnym sposobem bogacenia się [Arystoteles, 2007]. Chremastyka określa sposoby osiągania jak największego zysku, głównie z samych operacji finansowych. Celem staje się wówczas szybki zysk, a motywem bogacenie bez granic. Handel, ale jedynie w celu zaspokojenia własnych potrzeb, jest zajęciem godnym (np. „szewc i budowniczy, którzy postanowili dokonać wymiany swoich produktów - transakcja dojdzie do skutku, jeżeli buty zaspokoją potrzeby budowniczego $\mathrm{w}$ takim samym stopniu, w jakim wybudowany dom zaspokoi potrzeby szewca; potrzeba jest więc jedyną powszechną miarą wartości rzeczy, a umownym środkiem, zastępującym po- trzebę jest pieniądz" [ibidem]). Te rozważania dały początek nominalistycznej teorii pieniądza, zgodnie z którą istota wartości pieniądza nie wynika z jego wewnętrznej wartości, lecz jest oparta na powszechnym zaufaniu i uznaniu jako środka wymiany i miernika wartości. Arystoteles, podobnie jak Ksenofont, w swoich dziełach nawiązuje także do społecznego podziału pracy. Jego zdaniem wymusza on wymianę dóbr o różnej użyteczności. Taka wymiana wymaga jednak ich porównania i sprowadzenia do wspólnego mianownika, a to umożliwia pieniądz.

Wraz z upadkiem cesarstwa rzymskiego wV w. rozpoczął się nowy ustrój społeczno-polityczno-ekonomiczny: feudalizm. Kluczową rolę $\mathrm{w}$ kształtowaniu poglądów tamtych czasów miał Kościół katolicki. Wkład w rozwój myśli ekonomicznej wniósł św. Tomasz z Akwinu, który w dużym stopniu korzystał z dorobku Arystotelesa Według niego wytwarzane produkty są rezultatem współdziałania dwóch czynników produkcji - pracy i ziemi. To z kolei wyznacza ich wartość. Jako, że wymiana odbywa się głównie za pomocą pieniądza, wartość wymienna towaru występuje w postaci ceny. Cena natomiast jest powszechnie akceptowaną użytecznością dobra. Św. Tomasz pokazuje zależność ceny rynkowej od podaży i popytu na rynku, co jest zjawiskiem negatywnym dla gospodarki i społeczeństwa. Dlatego wskazuje na potrzebę ingerencji państwa i kościoła, które przez pryzmat zasad moralnych ustalałyby poziom tzw. cen sprawiedliwych. Cenę sprawiedliwą wyznaczają: ilość pracy potrzebna do wytworzenia towaru, koszty transportu i magazynowania oraz przynależność stanowa [Lipiński, 1968]. Św. Tomasz zakładał więc, że wytwórca, a także kupiec, nie powinien na transakcji nic zarobić. Ewentualna nadwyżka oznaczałaby wyzysk kupującego, a to z kolei jest sprzeniewierzeniem się wobec przykazania „nie kradnij". Z punktu widzenia moralnego, przekroczenie granicy ceny sprawiedliwej wiązało się z grzechem. Św. Tomasz w swoich rozważa- 
niach nie podawał jednak sposobu na wyznaczenie poziomu takiej ceny.

Odkrycia geograficzne oraz, związany z tym, rozwój handlu i kupiectwa był źródłem narodzenia się nowego kierunku poglądów ekonomicznych - merkantylizmu. Zakładał on, że bogactwo kraju jest tożsame z posiadaniem pieniądza kruszcowego. Jako że eksport towarów przyczynia się do zwiększania ilości pieniądza w kraju, natomiast import determinuje jego odpływ, merkantyliści postulowali utrzymywanie dodatniego bilansu handlowego. Początkowo merkantyliści uważali, że wartość kruszców szlachetnych jest stała, a zatem siła nabywcza pieniądza zależy od ilości zawartego w nim złota lub srebra. Z czasem jednak, w wyniku napływu dużej ilości kruszców szlachetnych do krajów europejskich, zauważono, że wraz z większą ilością pieniądza w obiegu, rosły również ceny towarów.

Wraz z postępującym społecznym podziałem pracy oraz nastaniem rewolucji przemysłowej, feudalizm został ostatecznie wyparty przez kapitalizm. W tym okresie rozważania nad wartością dóbr i ich ceną prowadził Adam Smith, przedstawiciel nurtu ekonomii klasycznej. W swoim dziele Badania nad natura i przyczyna bogactwa narodów głosi, że tylko praca zaopatruje naród we wszystkie niezbędne do życia środki, to praca stanowi miernik wartości wymiennej towarów. A. Smith pisze: „Rzeczywistą ceną każdej rzeczy, tym, co istotnie kosztuje ona osobę, która pragnie ją zdobyć, jest wysiłek i trud, z jakim ją zdobywa. Dla człowieka, który przedmiot nabył i który chce go zbyć lub wymienić na coś innego, rzeczywistą wartością tej rzeczy jest wysiłek i trud, którego sobie zaoszczędza, a którym może obciążyć innych ludzi" [Smith, 2007, s. 38-39]. Jednocześnie Smith zauważa, że miara wartości wymiennej towaru tylko z punktu widzenia zawartej w nim pracy ma zastosowanie w społeczeństwach prymitywnych, opartych na produkcji drobnotowarowej. W warunkach produkcji kapitalistycznej na wartość wymienną towaru wpływ mają trzy elementy: płaca, zysk oraz renta gruntowa. „W cenie zboża, na przykład, jedna część opłaca rentę właściciela ziemi, druga - płace robocze lub utrzymanie najemników i sprzężaju używanego przy produkcji, trzecia zaś - zyski dzierżawcy" [ibidem, s. 61]. Smith rozróżnia także pojęcia ceny naturalnej od rynkowej. Cena naturalna to cena wynikająca z przeciętnych stóp płacy, zysku i renty gruntowej. Ma ona charakter długookresowy. Cena rynkowa zależy od stosunku pomiędzy ilością towaru oferowanego na rynku, a efektywnym popytem na niego.

Karol Marks w dużej mierze czerpał w swoich rozważaniach z dorobku angielskiej ekonomii klasycznej oraz koncepcji francuskiego socjalizmu utopijnego'. Podjął próbę wyjaśnienia problemu transformacji, czyli trudności z wyjaśnieniem przejścia ze sfery produkcji, w której powstaje wartość towaru, do sfery podziału, w której występuje cena. W swoim podstawowym dziele - Kapitale głosił, że o wartości towaru decyduje praca, która jest w nim zmaterializowana. Wyróżnił dwa rodzaje pracy potrzebnej do wyprodukowania towaru: pracę konkretną i pracę abstrakcyjną. Efektem pracy konkretnej była wartość użytkowa towaru, a abstrakcyjnej - wartość wymienna. Marks zakładał wymianę ekwiwalentną i twierdził, że stosunek wymienny dwóch towarów odzwierciedla różnice pracy abstrakcyjnej mierzonej „niezbędnym czasem pracy" potrzebnym do wyprodukowania towarów. Na wartość towaru składały się: nakłady kapitału stałego (c), kapitału zmiennego (v) oraz wartości dodatkowej (m). Marks sformułował prawo wartości, zgodnie z którym w gospodarce wolnokonkurencyjnej cena rynkowa danego towaru nie musiała być równa wartości towaru. Przyczyną odchyleń ceny rynkowej od wartości była nierówność popytu i podaży. Odchylenia ceny rynkowej od wartości towarów produkowa-

\footnotetext{
Ideologia, która zakładała zniesienie własności prywatnej, będącej źródłem wyzysku i zamianę dotychczasowych stosunków wspólnotą majątkową i równością wszystkich obywateli.
} 
nych w różnych gałęziach gospodarki powodowały przepływy wolnych kapitałów z gałęzi nierentownych do rentownych i w efekcie wyrównywały się stopy zysku w całej gospodarce [Kundera, 2004, s. 119].

Cena, według Marksa, nie jest dobrym miernikiem wartości, gdyż w gospodarkach rozwiniętych obie kategorie mocno do siebie nie przystają: "Możliwość odchylania się cen od wartości tkwi w samej formie ceny" [Marks, 1955, s. 37]. Cena wówczas staje się osobną kategorią, która niekiedy może się zmieniać w sposób odmienny niż wartość. Determinantami określającymi cenę są popyt i podaż. „Popyt i podaż określają stale ceny towarów, nie pokrywają się jednak nigdy albo tylko przypadkowo" [ibidem, s. 56-57]. Marks uważał, że sprzedający pozbywają się towarów dlatego, że nie interesuje ich wartość użytkowa [Bartkowiak, 2008, s. 67].

Podstawą szkoły austriackiej, zwanej również psychologiczną, jest subiektywna teoria wartości. Zgodnie z nią wartość towaru utożsamiana jest $z$ indywidualnym odczuciem konsumenta. Z takiego założenia wynika malejąca użyteczność krańcowa dóbr, czyli spadek zadowolenia wynikający z konsumpcji każdego kolejnego dobra. Przedstawiciele szkoły austriackiej próbując mierzyć użyteczność posługują się kategorią kosztów, która jest rozumiana jako użyteczność dobra, mogącego mieć zastosowanie w wielu użytkach (celach) [Romanow, 1995, s. 37-39]. E. BöhmBawerk, kontynuując założenie dotyczące subiektywnej teorii wartości, tworzy teorię cen, zgodnie z którą cena rynkowa to wypadkowa różnych indywidualnych ocen wartości towaru na rynku, dokonanych przez nabywców i sprzedawców [ibidem, s. 39].

Szkoła neoklasyczna, której najwybitniejszymi przedstawicielami byli W.S. Jevons oraz A. Marshall, za główny czynnik motywujący do działalności gospodarczej uznaje potrzebę. Próbuje znaleźć „złoty środek" pomiędzy nurtem klasycznej ekonomii angielskiej, a szkołą austriacką. Uważa, że wartość i cena w równym stopniu zależy tak od czynników podażowych (koszty produkcji), jak od popytu związanego z użytecznością krańcową [ibidem, s. 40-43].

Szkoła lozańska (matematyczna) dążyła do stworzenia tzw. czystej ekonomii, czyli nauki abstrakcyjnej, która jednocześnie będzie ponadczasowa i uniwersalna. Według L. Walrasa głównymi cechami dóbr ekonomicznych są użyteczność i rzadkość. To z kolei powoduje konieczność ich wartościowania i wymiany. Pareto z kolei w swoich rozważaniach dąży do ograniczenia elementów subiektywnych przez zaniechanie mierzenia użyteczności. W tym celu posługuje się krzywą preferencji (obojętności), zgodnie z którą konsument potrafi porównywać użyteczność2.

Przedstawia ona wszystkie kombinacje dwóch dóbr dające konsumentowi taką samą całkowitą użyteczność, ponieważ w każdej z tych kombinacji jakiekolwiek zmniejszenie ilości jednego dobra zostaje zrekompensowane odpowiednim zwiększeniem ilości drugiego dobra [Oyrzanowski, 1995, s. 64]. Na osi współrzędnych istnieje wiele kombinacji, które dla konsumenta są jednakowo dobre. Taka krzywa obrazuje zjawisko substytucji dóbr. Jej kształt wynika z zastępowalności dobra im jest ona większa, tym krzywa obojętności jest mniej wypukła. Krzywych obojętności istnieje nieskończenie wiele, a za każdym razem konsument stara się wybrać tą, która daje mu największą satysfakcję. Ścieżka, która prowadzi do osiągnięcia kresu możliwości i pełnego zaspokojenia potrzeb (pagórek gustów) to krzywa preferencji. Analogiczny proces odbywa się po stronie podażowej. Producent dóbr również posiadając określone zasoby,

\footnotetext{
Użyteczność - zadowolenie konsumenta ze spożywanych dóbr; użyteczność jest kategorią czysto subiektywną, niepoddającą się obserwacji. Konsument nie może określić wartości użyteczności, może jedynie porównywać użyteczność dwóch dóbr i wówczas decyduje o tym, które z nich wybrać. Użyteczność ma charakterystykę malejącą. Krańcowa użyteczność jest malejąca, tzn. każde następne konsumowane dobro przynosi mniejszy wzrost użyteczności.
} 
stara się wykorzystać je możliwie najlepiej [Romanow, 1995, s. 45-46).

\section{Wartość we współczesnej ekonomii}

Słownikowa definicja wartości [Słownik, 2012, s. 312] określająca raczej powszechne rozumienie tego terminu, stanowi, że za wartość uznaje się: (1) to, ile coś jest warte pod względem materialnym, (2) cechę tego, co jest dobre pod jakimś względem, (3) posiadanie zalet, (4) zasady i przekonania będące podstawą przyjętych w danej społeczności norm etycznych, (5) liczbę określająca, ile jednostek zawiera dana wielkość fizyczna lub wielkość mogąca zastąpić wyrażenie algebraiczne, jego zmienne. Z perspektywy naukowej użyteczne kryterium klasyfikacji wartości wprowadził polski socjolog - Stanisław Ossowski [Ossowski, 1967, s. 73-75]. Dokonał on podziału na wartości uznawane (oparte na przekonaniach) i odczuwane (oparte na odczuciach). Te pierwsze bardziej cenimy rozumem, do tych drugich mamy wyraźny stosunek emocjonalny, np. cenimy sobie obowiązkowość, punktualność, ale emocjonalnie bliższa jest nam np. delikatność i wrażliwość. Jak zaznacza Ossowski ważnym ze społecznego punktu widzenia kryterium podziału wartości jest stopień kategoryczności ich obowiązywania. Ze względu na to kryterium dzielimy je na wartości kategoryczne (obowiązkowe) i preferencyjne (jedynie zalecane).

Porządkujące dla niniejszych rozważań wydaje się również spojrzenie Jensena [Jensen, 2005, s. 3-10), który wyróżnia 6 sposobów ujmowania wartości:

- religijny - wartość jako system wierzeń,

- behawioralny - wartość jako kategoria moralna i etyczna,

- ekonomiczny - wartość jako środek wymiany,

- użytkowy - wartość jako satysfakcja z posiadania,

- $\quad$ kulturowy - wartość jako znaczenie oraz symbol,
- wynikający z ludzkiej percepcji - wartość jako doświadczenie.

Z perspektywy ekonomicznej i użytkowej współcześnie dominujące próby uchwycenia pojęcia wartości można podzielić na dwa nurty:

- subiektywny, zgodnie z którym wartość dobra (lub usługi) ma charakter indywidualnej oceny, w jakim stopniu zaspokaja ono potrzeby człowieka; zatem źródło oceny wartości ma charakter zewnętrzny, dokonywany przez osobę, która dobro konsumuje,

- obiektywny (wewnętrzny), zgodnie z którym wartość dobra ma charakter immanentny, związany przede wszystkim z jego właściwościami; zgodnie z tym nurtem możliwe jest uchwycenie rzeczywistej wartości danego produktu.

Przedstawicielem pierwszego nurtu jest Ludvig von Mises. Jego zdaniem punktem wyjścia do określenia wartości dobra jest teoria wyboru konsumenta. Mises pisze: „(...) podstawą każdej decyzji człowieka jest wybór. Kiedy człowiek dokonuje wyboru, wybiera nie tylko między poszczególnymi rzeczami materialnymi i usługami. Jego wybór dotyczy także wszystkich wartości ludzkich. Oczami wyobraźni widzi wszystkie cele i środki, zarówno rzeczy materialne, jak i zagadnienia ze sfery idei, wzniosłe i pospolite, szlachetne i bezcenne; ocenia je i decyduje się na wybór któregoś z nich oraz odrzucenie pozostałych" [Mises, 2007, s. 4]. Uważa także, że nie da się zmierzyć takich wartości jak miłość, przyjaźń, przyjemność estetyczna. Podstawowym elementem motywującym ludzi do wymiany dóbr jest fakt, że cenią oni wartość dobra a nad dobro $b$. Pieniądz natomiast nie jest obiektywnym miernikiem wartości [ibidem, s. 177-178]. Zatem wzorzec analizy zgodnie z tzw. ekonomią Robinsona Cruzoe [por. Rothbard, 2007], w której badamy pojedyncze, odseparowane od społeczeństwa jednostki, nie ma racji bytu, gdyż nie uwzględnia się w nim interakcji zachodzących między tymi jednostkami. Na po- 
twierdzenie tego Mises pisze: „(...) zagadnienia ekonomiczne lub katalaktyczne są osadzone w ogólniejszej nauce i nie mogą być rozpatrywane w oderwaniu od niej. Właściwe podejście do problemów ekonomicznych musi rozpoczynać się od badania aktów wyboru; ekonomia staje się częścią - jak dotąd najbardziej rozwiniętą - uniwersalnej nauki, jaką jest prakseologia" [ibidem, s. 4].

Za przedstawiciela nurtu obiektywnego można uznać P. Burke’a [Burke, 2005], który wprowadza pojęcie wartości rzeczywistej (ang. real value / actual value). Jest to miara wartości dobra, którą można określić tylko w oparciu o narzędzia rachunkowe, które starają się uchwycić korzyści wynikające z konsumpcji danego dobra. Według Burke’a określanie wartości w oparciu o teorię popytu i podaży jest ryzykowne, gdyż te mają wrodzoną skłonność do manipulacji. Za przykład podaje wartość rzeczywistą książki zakupionej w księgarni przez studenta za 50 dolarów. Jeżeli owa książka nie przyniesie studentowi żadnej realnej (materialnej) korzyści, jej wartość jest równa zero. Jeżeli natomiast ten sam student kupi książkę w komisie i zapłaci za nią 0,25 dolara, ale wiedza, jaką zdobędzie, pozwoli mu zarobić w przyszłości 100.000 dolarów, to wartość książki jest właśnie taka. Burke proponuje zatem podejście do obliczania wartości dóbr i usług z perspektywy osiąganego zwrotu z inwestycji, a nie poniesionego wkładu pracy czy stanu równowagi pomiędzy popytem i podażą.

\section{Społeczna wartość dodana}

Społeczna wartość dodana jest kategorią z zasady ekonomiczną, skupiającą się na finansowym/liczbowym określeniu rezultatów działalności organizacji społecznej. Często jednak jest używana również w ogólniejszym znaczeniu i dlatego oba pojęcia używane są niejednokrotnie zamiennie. Analizując literaturę przedmiotu można znaleźć definicję społecznej wartości dodanej, zgodnie z którą jest to „dodatkowy zysk stanowiący pozytywny rezultat (dla ludzi, środowiska, dla wspólnoty lub dla lokalnej gospodarki) wytworzony przez organizację w trakcie tworzenia produktów lub dostarczania usług, za które klient czy odbiorca płaci" [Krawczyk et al., 2008, s. 94]. Definicja ta odnosi się do korzyści, jakie działania przynoszą społeczności w wymiarze długofalowego wpływu o charakterze społecznym lub środowiskowym [ibidem]. Przykładem tak opisanej społecznej wartości dodanej może być działalność polegająca na reintegracji zawodowej osób bezrobotnych i niepełnosprawnych. Dofinansowanie ze środków publicznych takiego przedsięwzięcia należy potraktować w kategoriach inwestycji społecznej. Poniesione nakłady są rekompensowane korzyściami, które można podzielić na te dające się wyrazić w wielkościach pieniężnych oraz takie, do których nie jesteśmy w stanie przypisać żadnej wielkości finansowej. Do pierwszej kategorii korzyści zalicza się m.in. zmniejszenie wartości transferów państwa z tytułu zasiłków dla osób bezrobotnych i niepełnosprawnych czy dodatkowe wpływy do budżetu wynikające z płatności podatku przez osoby dotychczas bierne zawodowo. Natomiast korzyści niekwantyfikowane pieniężnie to np. poczucie samorealizacji reintegrowanych osób, mniejszy poziom alkoholizmu w społeczeństwie czy ograniczenie zjawiska przemocy w rodzinie.

Postrzeganie społecznej wartości dodanej jako szerszej perspektywy przydatnej podczas analizy opłacalności przedsięwzięć społecznych zostało zaakcentowane przez K. Herbsta, który proponuje, żeby „zamiast terminu ekonomia społeczna używać terminu przedsięwzięcie o społecznej wartości dodanej". Podkreśla się w ten sposób, że mówimy o „zdrowej” działalności gospodarczej, realizującej jednakże rozszerzone spektrum wartości. Społeczna wartość dodana może być głównym celem przedsięwzięcia gospodarczego. W takim przypadku nie zawsze stosujemy kryterium zysku (akceptujemy stratę), 
ale nadal stosujemy instrumenty rachunku ekonomicznego i zarządzania gospodarczego. Takie podejście może mieć zastosowanie w realizacji pomocowych zadań władzy publicznej [Herbst, 2006, s. 3].

Społeczną wartość dodaną podmiotów ekonomii społecznej możemy zdefiniować również jako „stopień w jakim podmioty ekonomii społecznej są społecznie użyteczne" [Bohdziewicz-Lulewicz et al., 2011, s. 6]. Przez społeczną użyteczność rozumiemy tutaj stopień, w jakim te podmioty spełniają cele, które są przed nimi stawiane. Warto $w$ tym miejscu zauważyć, że definicja ta nie mówi wprost, jakie cele mają realizować tego typu podmioty, abyśmy mogli określić ich społeczną użyteczność. Cele te zatem nie są obiektywnie nadane, nie są też niezmienne. W takim razie, kto i w jaki sposób określa cele, które podmioty z sektora ekonomii społecznej powinny realizować? Odpowiedz jest niełatwa, wskazówek możemy jednak poszukiwać na gruncie:

a. literatury przedmiotu - polskiej i zagranicznej, w której opisane są dokładnie (i w dużej mierze pokrywają się) zarówno cechy tych podmiotów (np. oddolność, partycypacja w zarządzaniu, misyjność), jak i cele, dla których zostały powołane (np. tworzenie stałych miejsc pracy dla osób zagrożonych wykluczeniem społecznym, lub wręcz przeciwnie - tworzenie „przejściowych" miejsc pracy służących nabyciu doświadczenia i wiedzy oraz pomoc w znalezieniu pracy na „otwartym rynku”);

b. ustawodawstwa - duża część form prawnych w Polsce i zagranicą ma ustawowo określone cele społeczne, dla których może być powołana;

c. dokumentach strategicznych, w których planowanie polityki publicznej (np. łagodzącej skutki wysokiego bezrobocia wśród młodzieży) dokonuje się w oparciu o założenie, że PES skuteczniej niż inne instrumenty przyczyniają się do osiągnięcia zamierzonych, pozytywnych z perspektywy państwa skutków.
Istotną kwestią jest wyznaczenie „linii demarkacyjnej" pomiędzy pojęciami: społeczna wartość dodana a ekonomiczna wartość dodana (ang. economic value added). To ostatnie pojęcie zostało zastosowane przez amerykańską firmę konsultingową Stern Steward \& Company, która stworzyła narzędzie wspomagające duże przedsiębiorstwa w maksymalizacji wartości dla akcjonariuszy. Dotychczas dostępne miary oparte o proste stopy zwrotu nie sprawdziły się dla celów podejmowania decyzji strategicznych, gdyż nie obejmowały wartości kapitału intelektualnego firmy. Zaistniała więc potrzeba wypracowania nowej miary, która lepiej wspomagałaby kadrę zarządzającą. Ekonomiczna wartość dodana jest miarą uwzględniającą wszystkie elementy wpływające na zwiększenie lub zmniejszenie wartości firmy [Dobija, 2000, s. 67]. Pojęcie to jest o tyle istotne, gdyż także typowo komercyjne przedsiębiorstwa w ramach społecznej odpowiedzialności biznesu niekiedy podejmują działania mające charakter społeczny. Dobrymi przykładami są m.in. firma Danone, która prowadzi akcje dożywiania dzieci czy BP realizująca działania na rzecz ochrony środowiska. Tego typu aktywność przynosi korzyści dla otoczenia, ale wpływa także na wizerunek firmy, co z kolei zwiększa jej wartość. Powstaje zatem pytanie, czy taką działalność należy rozpatrywać w kategorii maksymalizacji ekonomicznej wartości dodanej, czy jest to jednak aktywność ukierunkowana na wytworzenie efektu społecznego.

\section{Podsumowanie}

Niniejszy artykuł jest wprowadzeniem do szerszego tematu, jakim jest pomiar społecznej wartości dodanej w sektorze ekonomii społecznej. Aby dostrzec efekty ekonomiczne wynikające z działalności podmiotów ekonomii społecznej, należało przywołać najważniejsze teorie wartości, które zostały sformułowane na przestrzeni wieków. Analiza ta pokazuje, że pojęcie wartości, a także spo- 
łecznej wartości dodanej nie mogą zostać sprowadzone do jednego ujęcia i zawsze mają wiele sposobów rozumienia. To z kolei determinuje sposób podejścia do pomiaru tych kategorii, który musi być odpowiednio dostosowany - zarówno do rodzaju wartości tworzonej przez podmioty ekonomii spo-

\section{Literatura}

Arystoteles (2007). Etyka nikomachejska. Warszawa: Wydawnictwo Naukowe PWN.

Bartkowiak R. (2008). Historia myśli ekonomicznej. Warszawa: Polskie Wydawnictwo Ekonomiczne.

Black J. (2008). Słownik ekonomii. Warszawa: Wydawnictwo Naukowe PWN.

Bohdziewicz - Lulewicz et al. (2011). Badanie społecznej wartości dodanej podmiotów ekonomii społecznej. Konceptualizacja metody pomiaru. Maszynopis.

Burke P. (2005). History and social theory. New York: Cornell University Press, New York.

Dobija D. (2000). „Możliwości pomiaru kapitału intelektualnego organizacji i jego prezentacji w sprawozdaniach finansowych", Zeszyty Naukowe, nr 553, Akademia Ekonomiczna w Krakowie.

Gumkowska M., Herbst J. (2008). Najważniejsze pytania - podstawowe fakty. Polski sektor pozarządowy 2008. Warszawa: Stowarzyszenie Klon/Jawor.

Herbst K. (2006). Czy ekonomia społeczna wspomoże rozwój lokalny? Warszawa: Fundacja Inicjatyw Społeczno-Ekonomicznych.

Honderlich T. (1998). Encyklopedia filozofii (Tom I), tłum. J. Łoziński. Poznań: Wydawnictwo Zysk i S-ka.

Jensen, P.A. (2005). .Value concepts and value based collaboration in building projects", Procedings of CIB W096 Architectural Management: ,Special Meeting' on Designing Value: New Directions in Architectural Management, vol. Publication no. 307, Kgs. Lyngby: Technical University of Denmark.

Kamerschen D., McKenzie R., Nardinelli C. (1991). Ekonomia. Gdańsk: Fundacja Gospodarcza NSZZ "Solidarność".

Krawczyk K., Kwiecińska D. (2008). „Audyt społeczny jako metoda oceny działalności przedsiębiorstw społecznych - na tle innych sposobów określania społecznej wartości dodanej", w: J. Hausner (red.), Wspieranie Ekonomii Społecznej. Kraków: Uniwersy- łecznej, jak i do specyfiki samego podmiotu i obszaru jego działalności. Autor planuje w kolejnym artykule dotyczącym tej problematyki przedstawić sposoby pomiaru dokonań w ekonomii społecznej w odniesieniu do metod pomiary w innych dziedzinach aktywności ludzkiej.

tet Ekonomiczny w Krakowie, Małopolska Szkoła Administracji Publicznej.

Ksenofont (1967). Pisma sokratyczne (O gospodarstwie). Warszawa: Państwowe Wydawnictwo Naukowe.

Kundera E. (2004). Słownik historii myśli ekonomicznej. Kraków: Oficyna Ekonomiczna.

Lipiński E. (1968). Historia powszechnej myśli ekonomicznej do roku 1870. Warszawa: Państwowe Wydawnictwo Naukowe.

Marks K. (1955). Kapitał, t. 2. Warszawa: Książka i Wiedza.

Martyniarczyk A. (red.) (2001). Powszechna encyklopedia filozofii. Lublin: Polskie Towarzystwo Tomasza z Akwinu.

Mises L. von (2007). Ludzkie działanie. Traktat o ekonomii. Warszawa: Instytut Ludwiga von Misesa.

Moore G.E. (1919). Zasady etyki, tłum. Cz. Znamierowski. Warszawa: Wydawnictwo M. Arcta.

Ossowski S. (1967). Z zagadnień psychologii społecznej. Warszawa: Państwowe Wydawnictwo Naukowe.

Ossowski S. (1967). Z zagadnień psychologii społecznej. Warszawa: PWN.

Oyrzanowski B. (1995). Mikroekonomia. Kraków: Wyd. Profesjonalnej Szkoły Biznesu.

Romanow Z. (1995). Teorie wartości i ceny w rozwoju myśli ekonomicznej. Poznań: Akademia Ekonomiczna w Poznaniu.

Rothbard M.N. (2007). Ekonomia wolnego rynku, t. I, tłum. R. Rudowski. Warszawa: Fijorr Publishing.

Samuelson P.A., Nordhaus W.D. (2006). Ekonomia. Tom 1. Warszawa: Wydawnictwo Naukowe PWN.

Słownik Języka Polskiego (2012). Warszawa: PWN.

Smith A. (2007). Badania nad naturą i przyczynami bogactwa narodów (tom I). Warszawa: Wydawnictwo Naukowe PWN.

Stiglitz J. (2004). Ekonomia sektora publicznego. Warszawa: Wydawnictwo Naukowe PWN.

\section{The value of the social economy}

Summary: The article is an overview of the most important theories of value, ranging from antiquity to modern times. Quoted, among others, are views on determining the value of goods and services of Aristotle, Adam Smith, Ludwig von Mises and Peter Burke. On the basis of these considerations, an attempt is made to formulate the definition of social added value created by the actors of the social economy, which will be the starting point to describe the methods of measuring achievements in the social economy.

Keywords: value, price, goods and services, money, monetization, social added value. 


\section{Prawa autorskie i licencja / Copyright and License}

(c) $(1 \Theta \Theta$
Artykuł opublikowano na licencji Creative Commons

Uznanie autorstwa - Użycie niekomercyjne - Bez utworów zależnych 3.0 Polska

http://creativecommons.org/licenses/by-nc-nd/3.0/pl/

This article is published under the terms of the Creative Commons

Attribution - NonCommercial - NoDerivs (CC BY-NC-ND 3.0) License

http://creativecommons.org/licenses/by-nc-nd/3.0/ 